\title{
THE ADAPTIVE REUSE OF CLOSED MILITARY BASES IN NEW ENGLAND
}

\author{
B. SCHLIEMANN ${ }^{1}$, J. MULLIN ${ }^{1}$, Z. KOTVAL-K ${ }^{2}$ \& Z. KOTVAL ${ }^{2}$ \\ ${ }^{1}$ Urban and Regional Planning, University of Massachusetts, USA \\ ${ }^{2}$ Urban and Regional Planning, Michigan State University, USA
}

\begin{abstract}
The United States Department of Defense (DOD), since World War II, has endeavoured to maintain hundreds of military facilities across the United States. Many of these facilities no longer meet the current or expected future defence needs of the nation. For this reason the DOD has embarked on a longterm programme of base closings across the country. The programme is fraught with angst, anger and fear as it touches millions of workers and the economic health of local communities and regions. Nonetheless, the results, to date, have been largely reasonable, well thought out, fair and mostly positive.

The purpose of this article is to describe and analyse the base closing experience in the six-state New England area of the United States since the end of World War II. Since that time 17 such installations have been closed. Only four remain. The article lays the foundation for how bases have been closed. It includes an overview and analysis of how bases were closed between 1945 and 1987 (the pre-BRAC era) and from 1988 through the present (the BRAC era). The article provides a concise case-by-case example of what has happened in terms of the closing processes to the 17 installations that have been closed across New England. This is followed by an interpretation of the results in the section 'Lessons Learnt'.

Keywords: adaptive reuse, community development, military base closings.
\end{abstract}

\section{INTRODUCTION: THE BASE CLOSING EXPERIENCE}

Over the past seventy years the nations of Europe and North America have maintained significant military forces as a deterrent to international conflict. These forces have required extensive spaces and structures for their training and operations. To illustrate this point, a US infantry division (15,000 soldiers) requires approximately 40,000 acres of land in order to fully prepare itself for possible deployment. These forts, camps, cantonments, training areas, airfields, navy yards and the like often have taken on the character of a civilian city with their own schools, churches, shopping centres, housing, recreation centres and movie theatres. Spread throughout the countries as a defensive measure, they frequently have been a major economic force for the host region. Over the past twenty years, largely due to technology and the changing nature of warfare, the need for many of these facilities has been steadily declining. In the United States, for example, beginning in 1960, nearly 200 military installations have been closed [1], and more will be closing in the near future.

The existing base infrastructure usually consists of office buildings, housing complexes, athletic facilities, golf courses, roads and vast open areas that may have considerable value for redevelopment or recreational space. These facilities often are in need of modernization or brownfield remediation before they can be put to private-sector use. The installation's real property is first offered to DOD's sister agencies and then other federal agencies before it is made available to the local community. This is the time when the Department of Housing and Urban Development and other stakeholders have an opportunity to address social imbalances

This paper is part of the Proceedings of the 3rd International Conference on Defence Sites: Heritage and Future (Defence Heritage 2016)

www.witconferences.com 
based on the unavailability of low-income housing as well as the needs of the homeless in the area, disparate poverty rates, and unemployment amongst different populations [2]. While the former base land was originally intended to be sold to local communities, it has been frequently transferred at no cost because of economic redevelopment concerns for those communities facing closure [3].

The closing of military bases is not free of controversy for several reasons. First, they result in economic disruption: military and civilian jobs are lost, housing prices decline, schools close and people are often forced to move from the area. Second, the installations are frequently contaminated with poorly disposed oil, gasoline, jet fuel and other environmentally degrading products. It has been only in the past three decades that the careful disposition of such products has occurred. And third, the governments have been less than proactive in removing the physical infrastructures that once serviced the military units. It is as if the installation was a ghost town.

While some progress is being made to eliminate the most egregious parts of base closings, there is more that must be done. More specifically, careful, thoughtful and sophisticated planning must be undertaken. This article is being written with this point in mind. It presents the best ten planning practices from the base closing experiences in the United States.

The base closure process offers an opportunity for the community to engage in planning for reuse options. The base realignment and closure (BRAC) process is mandated by the Defense Base Closure and Realignment Act of 1990. After considering the international threat situation, the Secretary of Defense determines the criteria for base closings and recommends a list of bases for closure. This list is then forwarded to an independent BRAC commission appointed by the President. The commission solicits input through regional public meetings and then provides their recommendation to the President who sends his recommendations to Congress for final approval. The President's recommendations cannot be modified by Congress. Bases can either be closed or realigned, indicating a change in mission, personnel or both. Communities form local redevelopment authorities (LRAs) to manage the transition of the base to civilian buildings. Bases must be closed within six years of the BRAC closure announcement [4].

The BRAC commissions have established criteria for equitable closure decisions; for the most recent commission, there are four 'military value' criteria including strategic mission of the installation and operational cost and four 'other considerations' including cost savings and environmental impact [5]. Amongst the published criteria, 'The economic impact on existing communities in the vicinity of military installations' is the sixth most important [6]. Ideally, the communities that lose bases have the potential to rejuvenate their economy fairly quickly; however, this is somewhat predicated on pre-existing economic and social conditions amongst the members of the community. Redevelopment on former military bases and industrial locations can take many years, and there are three impediments to resuming a community's economic health: '(1) Poor location and existing infrastructure; (2) A legacy of externalities, including environmental damage and high wages; and (3) A community and local leadership that has become dependent on a single employer or industry' [7]. While these concerns are worrisome, the Government Accountability Office (GAO) reports that unemployment rates are actually lower in almost two-thirds of communities which faced a BRAC closure [8].

The process for planning the recovery of an installation is controlled in the United States by the DOD who, in turn, typically designates one of the forces to take on the responsibility. The initial planning will focus on the legal status of the property; an inventory of the land, buildings and infrastructure; and an environmental assessment of the facility. The land must be 
inventoried from the perspective of its geological/topographical character and environmental conditions. It must be remembered that the military has had a long history of environmental negligence. In fact, it is only since the passage of the National Environmental Protection Act in 1969 that it has become committed to maintaining environmentally clean facilities. Concerning the built environment, the inventory will typically depict the military history of America throughout the 20th century. In times of active war, buildings were quickly built. However, once relative peace was achieved, they were largely left to decay. Whenever one enters a military facility originally built as part of the World War II effort, one will see the legacy of this policy. Buildings built for an effective life of five years are often still being used, 68 years after the war ended. However, in the aftermath of the Vietnam War, the military leadership opted for a change in policies. It determined that the quality of life of the American soldier needed to be upgraded if it was to recover its spirit. To accomplish this, a wide-scale demolition plan was developed to remove as much of the detritus of the past as possible. In its place new barracks, recreation facilities, family housing units, office complexes and even shopping centres of high quality, non-temporary, current design were constructed. The change, while not total (the World War II legacy was still noticeable), could not have been more remarkable.

The state of the infrastructure, as determined by the inventory, was commonly a mixture of both a positive asset and major liability. On the positive side, the cantonment area had all of the characteristics of a major city. Here one would find the water, sewer and electric systems that were necessary to operate the facility. In some cases, the cantonment of a training facility could service the equivalent of an Army division consisting of approximately 20,000 soldiers, thousands of their dependents and hundreds of civilian workers. These facilities commonly have been well maintained and represent a strong inducement for future users of the space. The liabilities are that, despite the high degree of maintenance, the systems tend to be dated and somewhat inefficient. While the military endeavoured to provide the needed systems on demand, cost was a secondary factor.

The BRAC process requires that a series of quantitative and qualitative studies be undertaken concerning the impacts of the closing on both the military and civilians. These studies from the military side will focus on the criticality of the facility for the national defence. From a civilian perspective they will focus on job losses, business closures, property declines and the loss of community services. They also will examine the impact on local, regional and state economics. Given that the base is always a major job producer and a critical part of the local market mix, this is clearly understandable.

\section{THE RESULTS OF BASE CLOSINGS}

What then have been the results of pre-BRAC and BRAC plans in New England? They have been decidedly mixed. Since the closing years of World War II, 17 active duty bases have been closed in the six-state region. Four now remain [9]. What has happened to the 17 bases closed?

In the pre-BRAC era (1944-1987), ten bases were closed. The earliest were Fort Ethan Allen in Colchester and Essex, Vermont, in 1944, even before the war ended. With minimal federal assistance, it is now a national historic site and houses a mix of tenants including the Vermont National Guard Headquarters, an airfield owned by the University of Vermont, a facility for St. Michael's College, as well as both residential and commercial buildings. If anything, in terms of uses, the Fort Ethan Allen conversion set the tone for those who followed. 
Concerning airbase conversions in the pre-BRAC era, most of them had one common element: their airfields were transformed, at least in part, to civilian facilities including Presque Isle (Presque Isle, Maine), Dover Air Force Base (Bangor, Maine), Bradley Field (Winsor, Connecticut), Westover Air Force Base (Chicopee, Massachusetts) and Quonset Point (Rhode Island). In the case of Dover and Bradley, the results have been quite impressive. Each has become a major airport with regular scheduled air service. Bradley, in fact, is the second largest commercial airport in New England. A second common factor is the continuing presence of the military in one form or another. In several cases (Bradley, Dover, Otis, Westover) there are either active duty elements or reserve forces still stationed at them. Indeed Otis now houses the largest coast guard air facility in the nation (Coast Guard Station Cape Cod). It is clear that airfields continue to be of value to the civilian community and, even after the base is formally closed, for military tenants.

These airfields also attracted civilian industrial and office facilities to locate either on the facility or nearby. This is not surprising, given the desirability of civilian air facilities, highway connectivity, flat lands and available infrastructure. For example, both Presque Isle and Westover have acres and acres of industrial facilities. Located in one of the most rural and poorest communities of Maine, Presque Isle could not possibly have built such a facility if it had to start with undeveloped land. Westover now houses 65 firms employing almost 4,000 workers. In the case of Bradley Field, it is still attracting industrial firms to its edges. These firms, quite simply, need to be close to an airport to best manage their supply chain and distribution channels.

The only Army facility to close in New England in the pre-BRAC era was the Springfield Armory (Springfield, Massachusetts). Rich in American history and a primary source of weaponry from the time of the American Revolution to the Vietnam War, it was summarily closed in 1968. At the time when it was closed it employed over 2,000 workers. Today it is a home to a National Historic Park, a community college consisting of 9,000 students and an industrial incubator consisting of 26 tenants. While it is not as significant a job and income generator as when the armory was at full production, it is the most positive iconic and economic force in one of the city's poorest areas.

There were major changes between pre-BRAC and BRAC closings. In the pre-BRAC era, the federal government, while a participant, was much more distant and informal in its role. Yes, it maintained the national interest but was quite accommodating to political and local interests. It also had little interest in long-term involvement. This changed dramatically after 1974 when a bill passed that required the DOD to undertake an environmental impact statement before closing a military facility. The process of undertaking such projects is costly, is full of citizen input and takes considerable time. The net result was that the DOD made no effort to close installations for more than 13 years. It further led to the formation of the BRAC and a clear process for closing excess bases.

Between 1988 and 2005, the BRAC process led to the closing of seven additional military facilities and bases in New England. They included two Army manufacturing facilities, one Army base, two air force bases and two naval air stations.

In 1988 the Army officially closed its Army Material Technology Laboratory located in Watertown, Massachusetts, ending approximately 172 years of military activity on the site. Over its lifespan as an Army facility, the site, most commonly called the Watertown Arsenal, manufactured ordinance of various types. Beginning with the simple machines to create cannonballs in 1816, it became so sophisticated in the 1960s that it had its own nuclear reactor. The site, at its peak, housed 10,000 workers and contained 131 acres, and 53 buildings in 
the densely populated town of Watertown quite close to the cities of Cambridge and Boston. While there were many reasons for the closing, the fact that the facility was dealing with highly sensitive explosions in a nuclear facility located in the heart of a region of 3.5 million stands out. Others included the fact that the facility was quite old and environmentally contaminated and that its mission could be better handled elsewhere [10].

The Watertown Arsenal began its slow-movement local closure in 1968 when the Army sold a 48-acre portion of the facility to the Watertown Redevelopment Authority (WRA). The WRA, after creating a plan, was able to attract a developer who, in turn, was able to entice a mall developer to create the highly successful Armory Mall. More development continued over the years to the point, by 2010, the site was overwhelmingly transformed with a centre of arts, a park and office complexes. Harvard University even purchased extensive acreage as an investment (It will pay the town of Watertown $\$ 480$ million over 52 years in lieu of taxes.) [10].

The site had several key factors that were influential in its revitalization. First, the community was well organized and, for the most part, moved in a common direction. Second, it was placed in the National Register of Historic Places, which gave it a sense of uniqueness and cachet. Third, it was proximal to the booming research and high technologies of Boston. And fourth, it was an Environmental Protection Agency Superfund site and listed on the National Priorities List (NPL).

The story of the second manufacturing facility is not nearly as positive. Seven years after the closure decision of the Watertown Arsenal, the Army in 1995 decided to close its engine plant in Stratford, Connecticut. The plant, first established in 1929, manufactured a wide variety of material ranging from seaplanes to truck engines. It was located on a beautiful 124-acre site along the Housatonic River adjunct to Sikorsky Airport and 3 miles from Long Island Sound. It also includes 49 buildings and a causeway to the river that was used to help launch seaplanes.

The Army fully lived up to its responsibilities and became an active participant in the conversion planning process working with 'Team Stratford'. This organization served as the local representatives for the project. The process continued for 11 years when finally the Army decided to auction the property for $\$ 9.6$ million. The winning bid, interestingly, went to a company that intended to attract a wide array of film production companies to the site with the intent of creating 'Hollywood East'. The company was unable to raise the funds and the facility continued its ghost-like status.

New England's last remaining major military post, Fort Devens, was declared excess on the BRAC list of 1991. The fort was originally created on land taken from four small towns Ayer, Shirley, Lancaster and Harvard - in what is today the far western fringe of Metropolitan Boston. Its purpose varied according to the needs of the Army. However, the post was quite small and was only capable of training small units or serving as a training school or command centre. At the time of its closure it provided 8,000 jobs and housed 15,000 residents $[11,12]$.

One of the most interesting factors related to the closing of Fort Devens was that it was inevitable. It was simply too small to serve as a facility for most Army functions. What's more, the functions offered at the former post were better co-located with combat troops. Thus, there were few large-scale protests or political action teams designed to serve the post. The stance of the state leadership at the time was to embrace the closing and begin transformation.

Given that the project involved multiple towns and counties it was quite logical that the state would become the lead organization. It formed the Devens Enterprise Commission 
(DEC) and gave it the mandate to act as if it was a town government. It also provided a wide array of funding mechanisms to help in the transition. From the beginning, the state realized that top-down planning would not work. With this point in mind it directed the DEC to undertake a comprehensive citizen participation effort. More than one hundred such meetings were held. By the time that the Army formally closed the base in 1996, a clearly articulated, wellfunded and well-supported plan was in place. The original and updated plans have worked quite well. The post, now called Devens, has attracted a significant number of industrial and commercial tenants and, as well, a federal prison medical facility and a branch of a community college [13].

Pease (New Hampshire) Air Force Base was selected for closure in 1988 as one of the first installations so selected under the first formal BRAC. Located in Portsmouth, New Hampshire, it is stationed within 50 miles of Boston. As with Fort Devens there was recognition that closure was highly likely and there was little protest. The State of New Hampshire moved aggressively to build a planning team and provided substantial grants and loans. The base consisted of approximately 4,200 acres, was immediately adjunct to the vibrant City of Portsmouth and had a strong infrastructure. The planning emphasized job growth, environmental quality, fiscal responsibility and economic vitality. It worked! Today the base houses the operations of the New Hampshire Air National Guard, a large wildlife refuge, an international airport and 600 acres dedicated for industrial and commercial development. By 2001, Pease led the nation in job creation when compared with all the bases closed between 1990 and 2000 [14]. Today it is approaching build-out with more than 200 companies and 6,800 employees on the former base [15].

Located in Aroostook County, Loring Air Force Base was closed in 1994 and was the county's major employer. The former base is only 5 miles from the Canadian border and is located in the most rural county in the west of the Mississippi River in the United States. It was the closest airbase in the Continental United States to Europe and played a major role in the Air Force's Strategic Air Command mission to deter aggression in the Cold War. The base, consisting of almost 9,000 acres, housed 10,000 military connected personnel. The payroll of the base represented $20 \%$ of the county's economy.

The state of Maine recognized the importance of Loring Air Force Base and had mounted a strong campaign to save the facility. Given the location of the base and its economic contributions this is quite understandable. After the closing was announced, the Loring Redevelopment Committee (LRC) was formed and prepared a plan that called for educational, office and commercial, industrial, residential and conservation/recreation establishments. The LRC was quite proficient in pursuing significant federal grants. Most notably, it received \$130 million to clean up a superfund site on the base. Perhaps more importantly, it accomplished this quite quickly. The role of the air force in assisting this was undertaken as part of the Installation Restoration Program. The recovery has been slow and steady. The demand for industrial and commercial buildings in this county is minimal. Moreover, unlike Devens, the LRC has stated policy that it will not 'raid' existing companies in the county to come to the base. It will endeavour to attract business from faraway places. It has been partially successful. Indeed, the majority of its jobs are governmental. However, with 1,400 civilian jobs on the facility, it has surpassed the civilian jobs that were employed when the base was active [16] (Dorrer, 2005). Given the fact that the base is so rural and so removed from vibrant economic activity, it is clear that Loring will take decades to recover.

The other Maine air facility that closed due to BRAC was the Brunswick Naval Air Station. Its experience couldn't have been more different from Loring's. Brunswick Naval Air Station 
was located in Brunswick along Casco Bay and the Androscoggin River. Built in 1943, the station grew and expanded until it was closed in May 2011. It ultimately impacted 4,000 naval and civilian personnel. Ironically, shortly before the closure was announced, the navy had invested more than $\$ 100$ million in capital improvements [17]. Moreover, Brunswick is an attractive and relatively affluent community.

Within months of the announcement, an LRA had been formed and planning began. By 2007, the plan had been approved and the Midcoast Regional Redevelopment Authority was created to manage the project. The plan called for a mix of facilities, including an airport, offices, an education park, recreation and open spaces, and business/technology facilities. It is a forward-looking plan that emphasizes industrial clusters, high technology and green industries. It clearly is building on the strengths of its region. Moreover, given that Bowdoin, the University of Maine and Southern Maine Community College are nearby, it has a strong education base to help meet the needs of high-end businesses. The funding for the implementation has come from both the state of Maine and the federal government.

It is clear that the leadership has reviewed the best practices from other places that have gone through the BRAC process. It is also clear that it focused on the fundamentals required to stimulate the transformation including creating a workable vision and a very effective citizen participation effort.

The experience of the South Weymouth Naval Air Station in Massachusetts has not been as successful as that of the Brunswick Naval Air Station. The South Weymouth Naval Air Station, located 12 miles from Boston, was built in 1943. Its purpose was to house and train pilots assigned to patrol the North Atlantic. The mission changed frequently until it became redundant. In 1995 the DOD announced its closure.

Given its location in the middle of Boston, its train and highway access, and the relatively well-maintained character of the post, one would have expected that this project would work as smoothly as that in Brunswick. It did not. Eighteen years after the announcement of closure, little progress has been made. Three major factors have led to this failure.

First, the station was placed in three towns (Abington, Rockland and Weymouth) with different values and aspirations. Community character is important! Second, unlike the other New England LRAs, the staff responsible for the project had considerable turnover. Given the extensive contentious and time-consuming citizen participation process associated with South Weymouth this can be understood. To date, hundreds of such meetings have been held. Third, the concepts proposed for the site have extended in a wide range of directions. Due to the variety of options and the fact that they have varied so wildly, there has been a large degree of distrust by the citizenry in the process. Finally, unlike Devens, the Commonwealth of Massachusetts has played a relatively minor role in revitalizing the station.

\section{LESSONS LEARNT}

3.1 Coalition building is an essential planning element that must be implemented immediately upon learning that a base could possibly be closed

This coalition should not have the saving of the installation as one of its mandates. It should, however, focus on how best to gain the resources to revitalize it. This cannot be successful at the local level but can work at a regional scale provided that professional staff and operational resources are procured. Most importantly, there is the need for the state to be a full active partner. In the case of Stratford and Weymouth the states have not been as aggressive 
as they are expected to be. This appears to be a major factor in the slow progress of these two places.

The revitalization plan must reflect the interests and goals of these places. Their leaders must have platforms to make their points and the citizens must be able to meaningfully participate in the process. While the pre-BRAC era top-down planning occurred quite frequently, it is rare now that the BRAC process has been implemented. Please note that the BRAC process calls for collection of the needs and interests of local communities: It does not mean that local conditions will guide the process. Base closings are too significant to be locally dominated.

\subsection{Planning process must be clear, transparent and fully funded}

The planning that follows a base closing is inevitably contentious. Indeed even in a clear, articulated process there is often extensive distrust. Such was the case at Pease and Devens. In the case of Devens, despite its success, there is a climate of suspicion and a feeling that the Commonwealth of Massachusetts is controlling the development of the district. Similar charges were made at Pease. In the case of Weymouth, the process, poorly defined throughout the project, has contributed to years of no progress.

The recovery of bases should not be handled by chambers of commerce, local planning offices or former politicians. They need to have dedicated and committed professionals. Yes, citizen input is crucial, and yes, all planning will ultimately become political. As well, volunteers can be helpful. However, given the complexity of the process, there are limits to what citizens can accomplish. Without a team of experts with skills ranging from environmental planning, urban revitalization planning, financial planning and grant writing, opportunities will be lost. Moreover, if there are not adequate resources to entice professionals to stay involved, success will be delayed.

\subsection{Military bases lend themselves to many different uses}

The continued use of space by the military after the base closings means that there is continued maintenance and vitality to the space. In most cases throughout the pre-BRAC and BRAC eras, the use of facilities by small active military, the Military Reserve and the National Guard has been viewed quite positively. There are two caveats. First, the troop training 'in the field' with all its accompanying noise, tremors, smoke and the like is viewed negatively. Thus, 'school house' activities are recommended. Second, if part of the base where the military is to be located takes on the character of a quality industrial or office park then the military must match this character.

Medical and education facilities are highly desired as tenants. Given that most installations have excellent classrooms, auditoriums, recreation areas, infirmaries and even hospitals on their grounds, they are excellent sites for such uses. In the case of New England, one can find community colleges, technical colleges, job training centres and even universities and four-year colleges located on the installations. Moreover, several have seen medical centres developing facilities on the post. These centres provide education, create higher skilled jobs, contribute to better health, lead to increases in salaries and wages and are positive attractions for industrial, commercial and residential uses.

New England has a scarcity of well-prepared industrial land. It is also one of the slowest growing sectors of its economy. If it is to welcome 21 st century cutting-edge manufacturing 
it must have the space. Many former installations have recognized this and set aside industrial land for the future. In fact, Loring's industrial park is the largest in the state of Maine.

There are opportunities to inexpensively gain needed municipal facilities but a thorough cost analysis is essential before accepting them. This is particularly the case with buildings that are more than 30 years old. The style (i.e., flat roofs), the energy efficiency, the environmental condition (i.e., presence of asbestos) and the ability to meet the building code are common issues. The first cost is rarely the last cost.

The communities, regions and states can obtain large tracts of land for open space, parks, conservation purposes and natural resources. This is a particularly strong popular positive result of base transformations. Loring, Pease and Brunswick have all been successful in creating protected open spaces. Indeed virtually every closed military installation in New England since World War II has resulted in an increase of protected open space.

\subsection{The historical aspects of the base are assets concerning their transformation}

The transformation of Springfield's Armory, the Boston Navy Yard and the Chelsea Naval Hospital has all greatly benefited from designations as national historic parks. With the designation come jobs, federal investment in buildings and tourists. The designation as parks is an announcement that this installation is an honoured, protected and safe place. It is interesting that three of the four remaining active duty bases are historic (Hanscom Air Force Base, New London Naval Submarine Base, Newport Naval Station and Portsmouth Naval Shipyard). Given their historical character and their urban locations in relatively vibrant communities, they will most likely not have great struggles should they become candidates for future BRAC actions.

\subsection{All base planning should reflect a long time frame}

Military base transformations must be integrated into the community. They should not be free-standing entities. For this reason, there must be a transitional zoning district as one moves into the original civilian community that reflects the new realities of the base. Too often these areas reflect the interests of the soldiers working on the base rather than the civilian community - how one finds Las Vegas-like honky-tonk bars, highway fast-food operations, used car dealers, strip clubs, and the ubiquitous adult entertainment business. There is a place for these functions; however, one must also recognize that they will have to change as the market changes.

\section{CONCLUSIONS}

Military installations have been necessary for national defence from the very beginning of the Puritan movement in New England. As the nation's defence needs change, old military installations will be closed or transformed and new ones will be built. The decisions related to the disposition of the long-standing installations are, for the most part, coldly rational and depend upon a complex set of factors related to affairs of state and the national defence. A look at the future unfortunately envisions no changes in the manner in which this occurs.

For New England, with a few exceptions, one will expect a continued withdrawal of the active military from the region. Hanscom, Portsmouth and New London have been considered as candidates under past BRAC programmes. If one was to make a prediction, New England's sole active duty facilities will be a high-tech centre at Hanscom, the Coast Guard 
Academy in New London and the Naval War College at Newport. In short, the New England region will contribute knowledge, innovation and creativity but not trained soldiers for defence needs.

\section{REFERENCES}

[1] Global Security, Base Realignment and Closure, available at http://www.globalsecurity. $\mathrm{org} / \mathrm{military} /$ facility/brac.htm, 2011 (accessed on 22 June 2011).

[2] U.S. Department of Housing and Urban Development, BRAC Process and Homeless Assistance, available at www.hud.gov, 2006, (accessed 22 November 2006).

[3] Siehl, G. \& Knight, E. Military Base Closures since 1988: Status and Employment Changes at the Community and State Level. Congressional Research Service, The Library of Congress, 17 June 1996.

[4] U.S. Army Corps of Engineers, New England District. Support to Military, available at www.nae.usace.army.mil/military.htm, 2009 (accessed 27 March 2009).

[5] Wynne, M.W. 2005 Base Closure and Realignment Selection Criteria. Memorandum signed by Michael W. Wynne, Acting under Secretary of Defense. 4 January 2005.

[6] Kane, M. Base Closings and Military Presence in the Northeast-Midwest: The Nation's Unguarded Region. Northeast-Midwest Institute, 2005.

[7] Mayer, H.J. \& Greenberg, M.R. Coming back from economic despair: Case studies of small- and medium-size American cities. Economic Development Quarterly, 15(3), pp. 203-216, 2001.

[8] Crock, S. The real math of military shutdowns. Business Week, 3622, p. 68, 1999.

[9] Viser, M. NE advocates push to overturn recommendations. Boston Globe website, www.bostonglobe.com, 2005 (accessed 6 July 2005).

[10] Siegel, L. The Watertown Arsenal, Massachusetts: A Restoration Success Story. Visit report, November 2006.

[11] Sasaki Associates, Inc. Devens Reuse Plan. 1 September 2006.

[12] Lindsay, J. Devens Wants to Start over as New Town. Sunday Republican. Springfield, Massachusetts. 24 September 2006.

[13] Office of Economic Adjustment. Economic Transition of BRAC Sites. Department of Defense. June 2005.

[14] Miller, J. Pease leads former bases in adding jobs. Auditors give Tradeport clean financial bill of health. The Union Leader. Manchester, New Hampshire. 5 October 2001: A12.

[15] Pease International, Pease International Home Page, available at http://www.peasedev. org, 2010 (accessed 14 June 2010).

[16] Dorrer, J. How Regions Adjust to Base Closing: The Case of Loring AFB Ten Years after Closure. Maine Department of Labor, November 2005.

[17] Portland Press Herald, Rethinking an economy; The pending closure of Brunswick Naval Air Station presents a generational challenge to the midcoast. Editorial in Portland Press Herald. Portland, Maine, 1 January 2006: C4. 